\title{
In vivo versus in vitro produced bovine ova: similarities and differences relevant for practical application
}

\author{
Peter Holm*, Henrik Callesen \\ Embryo Technology Center, Danish Institute of Agricultural Sciences, \\ PO Box 50, DK-8830 Tjele, Denmark
}

(Received 29 July 1998; accepted 20 October 1998)

\begin{abstract}
This present review describes some differences and similarities between bovine embryos produced in vivo and in vitro. The first part outlines the respective environments during maturation, fertilisation and early embryonic development of the two types of embryos and compares their morphological, biochemical and genomic characteristics. Results from comparative studies on embryo metabolism and gene expression reveal that most parameters are very similar, but some significant differences of presumptive importance for normal development have been described. Morphologic and kinetic differences between in vitro and in vivo produced embryos are also well documented. However, improved culture conditions have been reported to minimise the differences. The second part focuses on the practical consequences of the differences in relation to embryo selection, cryopreservation, sanitary risks and pregnancy following transfer as well as normality of calves. Lower viability following transfer and increased susceptibility to cryopreservation of in vitro produced embryos is discussed. Finally and most importantly, reported evidence of increased sanitary risks and abnormal foetal development associated with in vitro produced embryos is presented. (c) Inra/Elsevier, Paris.
\end{abstract}

preimplantation embryo / in vivo / in vitro / morphology / viability / sanitary risks / pregnancy

Résumé - Production d'embryons bovins in vivo et in vitro : similitudes et différences importantes pour l'application pratique. La présente revue décrit des différences et des similitudes entre embryons produit in vivo et in vitro. La première partie traite des environnements respectifs pendant la maturation, la fécondation et le début du développement des deux types d'embryons et compare leurs caractéristiques morphologiques, biochimiques et génomiques. Les résultats d'études comparatives sur le métabolisme embryonnaire et l'expression du génome révèlent que la plupart des paramètres sont semblables, mais des différences significatives d'importance présumée pour le développement ont été décrites. Des différences de la morphologie et de la cinétique de développement entre embryons produits in vitro et in vivo ont été aussi signalées. Cependant, des conditions de culture améliorées

\footnotetext{
* Correspondence and reprints

E-mail: Peter.Holm@agrsci.dk
} 
peuvent minimiser ces écarts. La deuxième partie porte sur les conséquences pratiques de ces différentes pour la sélection et la congélation des embryons, les risques sanitaires, la gestation après transfert et la normalité des veaux. La plus faible viabilité après transfert et la susceptibilité accrue à la congélation des embryons produits in vitro est discutée. Finalement, l'augmentation des risques sanitaires et d'un développement fœtal anormal associé aux embryons produits in vitro est soulignée. (C) Inra/Elsevier, Paris.

embryon preimplantation / in vivo / in vitro / morphologie / viabilité / risques sanitaires / gestation

\section{INTRODUCTION}

Production of embryos has become a highly valued technology that is commonly integrated into the conventional cattle breeding programmes $[24,25,96]$. Production of in vivo embryos from superovulated cows is still the most important of these embryo technologies, and it has been used fairly consistently during the last 5 years in Europe with 100-140 000 transferable embryos being produced annually [1]. However, in vitro production of embryos has become more efficient $[61,138]$ and oocytes are successfully collected transvaginally by ultrasound guided aspiration from cycling and early pregnant heifers and cows [103] Hence, an increasing number of embryos produced in vitro are transferred to recipients for commercial purposes, i.e. $6 \%$ of the commercially transferred embryos in Europe were produced in vitro in 1996 [57]

This 'in vitro success' has been achieved despite notable morphological, physiologi- cal and developmental differences (and similarities) between in vitro and in vivo produced embryos. These will be summarised in this review, which is divided into two parts. The first part will outline some of the differences and similarities between in vivo and in vitro produced (IVP) bovine embryos, and the second part will focus on some of the consequences of this for the practical application of the in vitro technique.

\section{IN VIVO VERSUS IN VITRO: DIFFERENCES AND SIMILARITIES (table I)}

\subsection{The ovarian follicle, oviduct and uterus}

In vivo produced oocytes and embryos develop in a complex and dynamic series of environments. First in the ovarian follicle, the growing and maturing oocytes achieve full developmental competence [66], then

Table I. Differences between the in vivo and in vitro environments.

\begin{tabular}{ll}
\hline In vivo & In vitro \\
\hline Maturation under follicular dominance & Maturation in artificial medium, complex or simple \\
Fertilisation in E2-primed oviduct & $\begin{array}{l}\text { Fertilisation in simple media } \\
\text { in presence of excessive sperm cells }\end{array}$ \\
Early development in the oviduct & Early development in medium \\
and uterus in developing luteal conditions & with/without somatic cells \\
Variation between cows & Variation between labs
\end{tabular}

See text for details and references. 
in the different portions of the oviduct during fertilisation and early precompaction development $[41,95]$ and finally in the uterus at the time of compaction and blastocoel formation (e.g. [9]) in yet another specific microenvironment [73, 89]. Though the superovulatory treatment has adverse effects on the follicular [22] and oviductal environment [62] as well as the subsequent maturation and fertilisation, respectively [49], the majority of the transferable embryos and resulting pregnancies are not different from embryos derived from unstimulated cows $[25,77]$.

The follicular environment of the oocyte changes dramatically prior to ovulation (for review, see [21]). One example is the shift in oestradiol/progesterone ratio triggered by the LH-surge [22]. The microenvironment of the oviduct is complex and varies also according to the oestrus cycle (for reviews, see $[33,81])$. The production of oviductal fluid is significantly higher during oestrous, though the concentrations of total protein (mostly albumin and immunoglobulin G) remain relatively stable around $1 \mathrm{mg} \cdot \mathrm{mL}^{-1}$ during the oestrus cycle [76]. Oviduct specific glycoproteins have been found to be associated with bovine oocytes and embryos [150] and are specifically secreted in the ampulla region within the first days of the oestrous cycle (for a review, see [95]). Other factors such as ionic composition and $\mathrm{pH}$ have also been reported to vary during the luteal phase [50,81]. Oviduct cells furthermore secrete a variety of vitamins, amino acids, fatty acids and growth factors (for reviews, see $[33,41,73])$. When the early in vivo produced embryo enters the uterine horn around its 16-32 cell stage [10], it is subjected to the final major microenvironmental change before the stage in which it is normally collected.

\subsection{The in vitro production system}

In comparison to the in vivo situation, the in vitro conditions are static apart from the intrinsic changes during the culture period induced by the oocytes/embryos themselves and the accompanying somatic cells. It is well documented that oocytes and embryos are affected both by specific physical conditions of the in vitro environment as well as more undefined constituents. Osmolarity and ionic composition, temperature, $\mathrm{pH}, \mathrm{CO}_{2}$ and $\mathrm{O}_{2}$ tension as well as culture volume are important parameters of the first category, and while serum and somatic cells are examples of the latter, all influence early embryo development in vitro (for reviews, see $[47,129])$. Complete in vitro production of embryos is normally carried out in three steps: in vitro maturation (IVM), in vitro fertilisation (IVF) and in vitro culture (IVC) until the blastocyst stage (for a comprehensive review, see [47]). IVM is most often accomplished in Tissue Culture Medium 199 (M199/TCM199) with Earle's salts supplemented with a mixture of gonadotrophins, oestradiol, pyruvate, growth factors and/or serum. Most immature oocytes used for in vitro embryo production are collected from 2-6 mm follicles. Therefore, as mentioned earlier, they are prevented from undergoing controlled capacitation and final maturation under dynamic conditions as it occurs in vivo under follicular dominance prior to the LH-surge and in the ovulating follicle after the LH-surge [66], respectively.

A very commonly used medium for IVF of bovine oocytes is Tyrode's albumin lactate pyruvate medium (TALP) supplemented with heparin, epinephrine, hypotaurine and penicillamine as described by Parrish et al. [100]. However, Brackett and Oliphant's defined medium (DM) supplemented with bovine serum albumin (BSA) or poly-vinyl alcohol (PVA) [75] as well as synthetic oviduct fluid (SOF) with serum $[30,61]$ also have been used successfully in the cow in combination with heparin and/or caffeine treatment of sperm cells. The calcium concentration in these media is generally lower than in the oviductal fluid (1.8-2.2 mM versus around $3.1 \mathrm{mM}$ ). Under IVF conditions, the sperm/oocyte ratios are generally much 
higher than in vivo: in the range of 100 000-200 000:1 compared to close to $1: 1$ in vivo [63]. Cumulus cells surrounding the oocytes are most often not removed prior to IVF. Their presence appears to be beneficial for the acrosomal reaction of the sperm cells, and mechanical or enzymatic removal of the cumulus cells may damage the oocyte as well as increase the incidence of polyspermy (for a review, see [47]).

Conditions for IVC vary greatly between the three major approaches to embryo culture: IVC in the presence or absence of somatic cells, or IVC in medium conditioned by somatic cells. The presence of somatic cells has been shown to be essential in some complex media in order to support bovine embryos through the $8-16$ cell stage (e.g. $[26,34])$. In simpler media, similar development of bovine embryos was obtained by serum supplementation (e.g. [91]) or under defined/semi-defined conditions using BSA or PVA together with amino acids (e.g. [61, $75,104,115])$. The most commonly used types of somatic cells are oviduct, granulosa, Vero and buffalo rat liver cells, while media for bovine co-culturing and conditioning of media are serum supplemented M199 and Menezo's B2-media. The dominating simple media for bovine IVC in the absence of somatic cells are probably SOF [127] and CR1 [116] supplemented with amino acids (SOF: [126], CR1: [115]). However, M199 also can be used with rel- atively high success rates without somatic cells if the oxygen tension is lowered [39]. Culture conditions in the absence of cells can be more or less defined depending on supplementation with serum, albumin or PVA or on preconditioning of media [129].

Nevertheless, despite a profound influence of the in vitro conditions on embryo development, morphology and metabolism, similar embryo development can be obtained in very different conditions [131].

\subsection{The matured oocytes (table $I I$ )}

IVM oocytes are aspirated from their normal environment in the tertiary follicles of more than 2 to $3 \mathrm{~mm}$ in diameter, at which follicular stage more than $70 \%$ of the oocytes will have achieved full meiotic competence and undergo spontaneous meiotic maturation within $24 \mathrm{~h}$ in culture $[32,36]$. In contrast, in vivo matured oocytes have been allowed to fulfil their capacitation or prematuration under follicular dominance prior to the start of final maturation signalled by the preovulatory LH-surge (for a review, see [66]). During this period the oocyte is significantly modulated (e.g. organelle location, nucleolar activity, gene expression, protein synthesis and post-transductional modifications) in order to acquire full developmental competence. The importance of this is reflected in the better developmen-

Table II. Differences between in vivo and in vitro matured oocytes.

\begin{tabular}{ll}
\hline In vivo & In vitro \\
\hline $\begin{array}{l}\text { Prematured (capacitated) under } \\
\text { follicular dominance }\end{array}$ & $\begin{array}{l}\text { Exposed to decomposing follicular environment } \\
\text { for } 0-8 \mathrm{~h} \text { between slaughter and oocyte collection }\end{array}$ \\
$\begin{array}{l}\text { Clear perivitelline space } \\
\text { Highly expanded cumulus lost within } \\
\text { a few hours after ovulation }\end{array}$ & $\begin{array}{l}\text { Dislocation of cortical granules } \\
\begin{array}{l}\text { High developmental competence } \\
\text { following fertilisation }\end{array}\end{array}$ \\
\hline
\end{tabular}

See text for details and references. 
tal competence of in vivo embryos compared to in vitro (for a review, see [114]), as well as in the observation that immature oocytes aspirated from larger follicles (>6-8 mm) are more developmentally competent than oocytes from smaller follicles $[15,35,86,102]$. Interestingly, recent data suggest that post-mortem incubation of slaughterhouse ovaries for $4 \mathrm{~h}$ prior to oocyte aspiration is able to enhance developmental competence in vitro $[16,121]$. Post-mortem incubation of ovaries may mimic the conditions of follicular atresia, which also has been linked to higher developmental as grade 3 oocytes of which most derived from follicles with beginning signs of atresia developed better in vitro than other classes of oocytes [15].

Morphologically, a high proportion of in vitro matured oocytes has been reported to be diploid [80]. Furthermore, it is known that the migration of cortical granules is impaired [64], which is likely to affect their release at fertilisation and subsequent block against polyspermy (e.g. [157]). In superovulated cows, fertilisation measured as embryo cleavage averages around $75 \%$ (e.g. [53]), which is similar to what is achieved after IVF of in vitro matured oocytes (e.g. [47]). Yet, in vivo derived zygotes also develop to the blastocyst stage more frequently than in vitro zygotes (e.g. [141]).
Polyspermy and asynchronous development of pronuclei are frequent deviations following in vitro fertilisation $[77,157]$. Both events appear to be affected by the presence or source of serum-protein in the fertilisation medium $[31,125]$.

Under in vivo conditions the oocytes will have lost their expanded cumulus cells within a few hours after ovulation [88] and relatively few selected sperm cells are present at fertilisation in the oviduct $[63,65]$. The number of accessory sperm cells found in the zona pellucida of in vivo zygotes varies from only 5 to 75 [55]. In contrast, IVM oocytes are generally still enclosed by cumulus cells at fertilisation, and the sperm/oocyte ratio is very high in vitro, as the normal concentration of sperm cells in the fertilisation medium is $1-2 \times 10^{6} \mathrm{sperm} \cdot \mathrm{mL}^{-1}$ for $100-200$ oocytes $\cdot \mathrm{mL}^{-1}$.

\subsection{The early bovine embryo}

Morphologically, IVP embryos differ from in vivo embryos right from the first cell cycle and in a number of ways (table III).

- IVP embryos generally appear darker $[106,130,141]$. This has been associated with a higher accumulation of lipid or lipidlike granules in the cytoplasm due to the

Table III. Morphological differences between early bovine embryos produced in vivo and in vitro.

In vivo In vitro

$26 \%$ mixoploid

Light, round, distinguishable blastomeres

Tight compaction

Early blastocysts around 100 cells

$\geq 1 / 3$ ICM of total cells
$72 \%$ mixoploid

Darker, swollen blastomeres

Retarded fourth cell cycle

Impaired compaction

Premature blastulation at around 32 cells

$\leq 1 / 3$ ICM of total cells

See text for details and references. 
use of serum in the culture medium, as the phenomenon can be avoided by culturing embryos in serum-free media $[43,133]$. The degree of darkness and granulation depends on the source of serum with human serum causing the largest change in morphology. High lipid contents of bovine IVP embryos have been linked to the lower buoyant density of IVP embryos compared to in vivo embryos [107, 108].

- Blastomeres appear more swollen and the perivitelline space is smaller at all precompaction stages of IVP embryos [61, 106, 141].

- At the morulae stage and under some conditions IVP embryos show less obvious compaction and shrinkage of the blastomeres $[54,61,106,141]$. However, experience from the author's laboratory has shown that the degree of compaction is highly influenced by the culture medium, thus serum-free modified SOFaa medium causes substantially tighter compaction than Medium 199 with granulosa cell co-culture [60].

- Compaction takes place around the 32 -cell stage both in vivo and in vitro [10, $61,143,145]$. However, in vivo derived early blastocysts normally consist of about 100 cells [10], while in vitro embryos are observed to form their blastocoel cavity very soon after reaching the early morula stage without proper compaction [61, 109, 141, $145,160]$.

- Embryo development is reported to be slower in vitro, but this is significantly influenced by culture medium (serum: 105, 132, 140, 160]; co-culture cells and medium: [54, 56]; for a review, see [129]).

- The number of inner cell mass cells is generally lower in vitro, varying from the normal number (i.e. more than one third of the total cell number as seen in vivo); this again depends on the culture system used $[28,69,143]$.

It has generally been accepted that in vitro embryos develop slower than in vivo produced embryos due to a retarded development through the fourth cell cycle $[7,51$, 61]. This particular cell cycle is associated with a very crucial event in embryogenesis, namely the major transition from maternal to embryonic control (e.g. [8]). In vitro, the lengths of the first cell cycles are correlated with embryo viability $[51,61]$, and improved culture conditions appear to shorten the length of the fourth cell cycle in particular [61], thus facilitating the genomic transition.

In vitro, male and female embryos have been reported to develop at different speeds [5, 158, 159]. However, evidence also suggests this to be linked to culture conditions $[20,61,87,123]$. This sex related difference has also been reported for in vivo produced embryos [3, 68]; however, due to asynchronous ovulations in superovulated cows it is difficult to investigate in vivo embryos [10]. Furthermore, no relation between developmental stages and sex of in vivo produced embryos was found in a large field trial in Denmark [23].

Chromosomal abnormalities also influence in vitro embryo development substantially, and the incidence of this has been observed to be high in IVP embryos (15-30\%) $[70,74]$. The incidence in vivo has been estimated to be $7-10 \%$ (W.A. King cited by [74]). Preliminary results from an ongoing study have shown that $72 \%$ of 151 IVP blastocysts were mixoploid, but the majority of these $(60 \%)$ had less than $10 \%$ cells with abnormal ploidy. In contrast, only $26 \%$ of 19 in vivo produced blastocysts that have been examined so far were mixoploid, and all of these had less than $10 \%$ polyploid cells [D. Viuff and T. Greve, pers. comm.].

IVP and in vivo produced embryos differ in respect to their metabolism (e.g. oxygen, glucose, pyruvate and lactate uptake and utilisation; for reviews, see $[42,113,130]$. Nevertheless, only a few studies directly compare the metabolism of ruminant embryos produced in vivo versus in vitro (amino acid uptake: [101]; pyruvate utili- 
sation: [129]; glucose utilisation: [132]). Furthermore, culture conditions (e.g. coculture versus conditioned medium, glucose and lactate concentrations, amino acid supplementation and protein source) also affect embryo metabolism and consequently development [43, 114]. In summary, adenosine triphosphate, oxygen and glucose uptake and pyruvate utilisation appear to be comparable between in vivo and IVP embryos, but vary on a cellular basis (summarized by Thompson [135]), while the amino acid uptake is about $30 \%$ lower for bovine IVP embryos cultured in serum-free conditions [101].

The patterns of synthesised proteins of in vivo and IVP bovine embryos [7] as well as the mRNA-synthesis [A.J. Watson, pers. comm.] have been reported to be very similar. However, studies employing reversetranscriptase polymerase chain reaction (PCR) methods have revealed significant differences between the relative abundance of some developmentally important gene transcripts at the bovine morulae or blastocyst stages [152-154]. These authors reported a significantly lower expression of the connexin 43 gene (important for intercellular communication via gap junctions) and the glucose transporter-1 gene (important for glucose metabolism) in postcompaction bovine IVP embryos. The heat shock protein 70.1 gene was, on the other hand, expressed at a higher level in IVP blastocysts cultured in the presence of oestrus cow serum than in both blastocysts cultured in the absence of serum and produced in vivo. Other genes (i.e. desmosomal protein genes for plakophilin and desmocollins II and III, poly(A)-polymerase gene and trophoblast protein gene) were expressed similarly in in vivo and in vitro morulae and blastocysts. Other groups are investigating the expression of candidate genes underlying the large offspring syndrome (e.g. insulin-growth factor 2 gene) in embryos derived from different sources using similar techniques [161].

\section{IN VIVO VERSUS IN VITRO: PRACTICAL CONSEQUENCES}

\subsection{Selection for viability}

Classification on the basis of the developmental stage and cellular appearance has been shown to be a practical and relevant way of evaluating the viability of both in vivo $[53,84]$ and in vitro produced bovine embryos $[54,110]$. However, the diverse morphological and physiological characteristics reported for IVP embryos and the influence of culture conditions on these parameters make uniform evaluation and comparisons between IVP embryos from different laboratories very difficult. Better agreement among different evaluators can be obtained either by sucrose induced shrinkage of IVP embryos, thus allowing improved visualisation of extruded cells and cellular material [144], or by using the simpler classification system based on three versus four embryo quality categories of Farin et al. [38]. However, pregnancy rates are lower following transfer of IVP embryos compared to in vivo derived embryos of similar classification (see table IV). Additional selection methods may thus be needed to achieve a better discrimination between viable and non-viable in vitro embryos. Embryo metabolism (i.e. measurements of glucose, pyruvate, oxygen uptake and/or lactate production $[44,98,99,112])$ and kinetics (time intervals between cleavage events $[46,51,61])$ have both been associated with viability of individual embryos and thus suggested as tools for improved embryo selection.

\subsection{Handling in relation to cryopreservation}

IVP embryos are more adversely affected by chilling than in vivo embryos. Most pronounced is the effect at the morula stage, which does not survive cooling below $15^{\circ} \mathrm{C}$ in normal medium $[107,108]$. This increased 
Table IV. Differences in pregnancy rates, incidence of congenital defects and birth weight of calves following transfer of in vivo and in vitro produced bovine embryos.

\begin{tabular}{llrr}
\hline Parameter & & \multicolumn{1}{c}{ Vitro } & \multicolumn{1}{c}{ Vivo } \\
\hline Pregnancy rates & Fresh & $40-50 \%$ & $50-75 \%$ \\
& Frozen & $10-40 \%$ & $40-70 \%$ \\
Abortion rates & $>60$ days & $7-24 \%$ & $3-5 \%$ \\
$\begin{array}{l}\text { Congenital } \\
\text { defects }\end{array}$ & & & \\
& Overall & $3-5 \%$ & $0.5-2 \%$ \\
Birth weight & $>50 \mathrm{~kg}$ & $0.5-2 \%$ & $<0.02 \%$ \\
& $>60 \mathrm{~kg}$ & $>30 \%$ & $<10 \%$ \\
\hline
\end{tabular}

See text for details and references.

sensitivity to cryopreservation procedures is a major obstacle for a more widespread use of the IVP technique in cattle breeding [40]. Evidence suggests that the sensitivity to cooling and freezing is related to the relative higher lipid contents often found in IVP embryos (see earlier), and is thus also related to the lower buoyant density of IVP embryos compared to in vivo embryos [107, 108]. Removal of the lipid vacuoles in porcine zygotes has been shown to cause survival following freezing of stages that normally do not tolerate freezing [94]. Similar treatments of bovine IVP embryos have also improved their survival substantially $[28,83,137]$. However, such a radical approach is not practical for routine work.

Some studies indicate that cryopreservation by vitrification results in better survival than conventional slow freezing of IVP embryos following transfer $[111,156]$ while others do not [2, 79, 97]. Experience from our laboratory shows that vitrification by the open pulled straw (OPS) method allows successful cryopreservation of days 2, 3 and 4 in vitro produced embryos with postwarming day 8 blastocyst rates of 27,43 and $52 \%$, respectively [139]. Freezability of IVP embryos can also be affected by culture conditions (for a review, see [90]). For instance, the presence of serum has been shown to influence embryo survival fol- lowing cryopreservation negatively [ 128 , 136], while co-culture of embryos with Buffalo rat liver (BRL) cells seem to enhance survival after freezing [146]. Hence, manipulation of the culture conditions appears at present to be one suitable way of improving survival after cryopreservation of in vitro embryos.

\subsection{Handling in relation to sanitary risks}

Handling of IVP embryos implies specific sanitary risks that differ from the in vivo situation. The main risk of transferring diseases with embryos relates to the association of pathogens with the zona pellucida (for reviews, see $[11,52,124]$ ). The structure of the zona pellucida differs between IVP and in vivo embryos with respect to the exposure and coating of the zona pellucida to oviductal glycoproteins (e.g. [150]) and its resistance to proteases (lower in IVP embryos) [107]. Furthermore, the large number of sperm cells penetrating into the zona pellucida of IVM oocytes still surrounded by cumulus cells at the time of fertilisation also constitutes additional sanitary risks, as contaminated sperm cells appear to be able to introduce pathogens into the IVP system [124]. Additionally dur- 
ing culture, IVP embryos are most often exposed to undefined biological materials (e.g. serum, BSA, hormones, heparin and somatic cells) that may be contaminated with pathogens. The recommended standard washing procedures [67] will remove most known viruses and bacteria from bovine in vivo produced embryos with intact zona pellucida, while this is not the case for IVP embryos [52]. The risks of infecting the IVP embryos with bovine herpesvirus-1 (BHV-1) and bovine viral diarrhoea virus (BVDV) have had special attention. First, these viruses will not be eliminated from contaminated embryos by the usual washing procedure, even with the use of trypsin [13, $14,17,52,162]$. Second, BVDV and/or BHV-1 can be isolated from ovarian tissue and oviductal cells of infected animals [12, 18 ] and with subsequent frequent contamination of the IVP systems as a result $[6,85]$. And third, contamination with BVD and/or BHV-1 seems not to reduce the embryo blastocyst rates (e.g. $[19,162]$ ). At present, no definite guidelines are available for the proper washing procedure of in vitro embryos.

\subsection{Pregnancies and calves (table IV)}

It is generally accepted that the viability of IVP embryos is reduced compared to their in vivo counterparts, and this difference is even more obvious following cryopreservation (see earlier). Pregnancy rates following transfer of IVP embryos compared to in vivo derived embryos are around $40-50 \%$ versus $50-70 \%[37,40,48,54,92,111$, $155,156]$; however, pregnancy rates over $50 \%$ have been achieved in commercial settings following transfer of fresh day 7 IVP embryos of good to excellent quality [54]. Pregnancy results following transfer of cryopreserved IVP embryos are often very low, ranging from $10-40 \%[40,54,58,79,111]$.

Pregnancy loss following transfer of IVP embryos is not only higher in early gestation prior to day 23 , but abortion rates after
2 months of gestation is also higher (7-24\%) $[54,78,110,111,135,142]$ compared to pregnancies with in vivo derived embryos (around $5 \%$ ) $[24,25,77]$. These late abortions combined with reports of increased incidence of miscarriages, disturbed foetal development, higher birth weights, dystocia, weak calves and/or perinatal death [9, $37,78,93,117,119,147]$ are the most disturbing features of the IVP technique at present. The overall incidence of congenital defects has been reported to be more than twice as high in IVP calves than in embryo transfer/artificial insemination (ET/AI) calves (3.2-5.2\% versus $0.6-2.2 \%$ ) [78, 147]. More specifically, hydroallantois has been observed in $0.5-1.8 \%$ of the IVP pregnancies $[54,147]$, for which the normal rate is about 1 in 7500 [122]. IVP calves have been reported to weigh around $10 \%$ more than normal AI calves [147]. Kruip and den Daas [78] reported that the percentage of calves weighing more than 50 and $60 \mathrm{~kg}$, respectively, were $\leq 10 \%$ versus $\geq 32 \%$ and $\leq 4 \%$ versus $\geq 6 \%$ for in vivo compared to IVP calves. In the two latter studies, the incidence of perinatal death was also significantly higher for IVP calves $(9-14 \%)$ compared to in vivo calves $(6 \%)$.

The effects of in vitro culture on gestation and offspring was first reported in sheep [148] (for a review, see [149]). In this species, the problems regarding the oversized offspring are associated with the presence of human serum [133] as well as sheep [B. Brown, pers. comm.] and bovine serum [120] and somatic cells [120] in the culture medium. This is not evident in cattle [72, 135]. Manipulation of the oocyte as in IVMIVF has also been reported to cause increased birth weight in sheep [59], and the syndrome itself is a well-known problem in nuclear transfer calves (e.g. [45, 151]). Evidence from nuclear transfer calves suggests abnormal in utero energy regulation as a causing factor, as thyroxine, tri-iodothyronine and insulin concentrations were altered in these calves compared to control calves [45]. 
Preliminary data from an ongoing physiology study on the metabolism in foetal and premature newborn calves derived from IVP embryos suggest lower plasma cortisol concentrations in IVP calves than in AI controls, which may contribute to the problems regarding prolonged gestation, higher birth weight and lower viability [71]. An ongoing investigation conducted by the present authors in collaboration with the latter research group monitors similar physiological parameters in newborn mature calves derived from IVP embryos cultured either in the presence of serum and oviduct cells or in defined conditions. None of the calves born so far (five after serum co-culture and six after defined culture) have differed from control AI calves with respect to viability, behaviour and physical appearance [72, 118]. However, the incidence of observed abnormalities in IVP calves varies greatly between laboratories [78], which is likely to be a reflection of different in vitro culture conditions.

\section{CONCLUSION}

The fact that in vitro production of embryos works at the level described is remarkable. The fundamental differences under which the ovum passes through the events of maturation, fertilisation and early embryonic development in vitro as compared to the natural in vivo situation is an example of the enormous tolerance and adaptation power of the reproductive process. It also reflects our present ability to culture cells in vitro until the pre-elongation embryo stages, which is the period in which in vivo embryos are also cultured within the genital tract.

Within the last few years, in vitro embryo production has become very successful and much new information in both the basic understanding and the consequences has been obtained. Similar progress is necessary in the future in order to reduce the differences between in vitro and in vivo derived embryos. The consequences on pre- and post-natal development of the calves must be examined in particular to avoid restrictions in the future use of the in vitro techniques due to bioethical considerations.

\section{REFERENCES}

[1] AETE, Proc. 9th-13th Sci. Meet. Eur. Emb. Trans. Soc. 1993-1997.

[2] Agca Y., Monson R.L., Northey D.L., Schaefer D.M., Rutledge J.J., Post-thaw pregnancy rates comparison of vitrified and frozen in-vitro produced bovine embryos, Theriogenology 45 (1996) 175 (abstr.).

[3] Avery B., Impact of asynchronous ovulations on the expression of sex-dependent growth rate in bovine preimplantation embryos, J. Reprod. Fert. 87 (1989) 627-631.

[4] Avery B., Bak A., Schmidt M., Differential cleavage rates and sex determination in bovine embryos, Theriogenology 32 (1989) 139-147.

[5] Avery B., Jørgensen C.B., Madison V., Greve T., Morphological development and sex of bovine in vitro fertilized embryos, Mol. Reprod. Dev. 32 (1992) 265-270.

[6] Avery B., Greve T., Rønsholt L., Botner A., Virus screening of a bovine in vitro culture production system, Vet. Rec. 132 (1993) 660.

[7] Barnes F.L., Eyestone W.H., Early cleavage and the maternal zygotic transition in bovine embryos, Theriogenology 33 (1990) 141-152.

[8] Barnes F.L., First N.L., Embryonic transcription in in vitro cultured bovine embryos, Mol. Reprod. Dev. 29 (1991) 117-123.

[9] Behboodi E., Anderson G.B., BonDurant R.H., Cargill S.L., Kreusher B.R., Medrano J.F., Murray J.D., Birth of large calves that developed from in vitro-derived bovine embryos, Theriogenology 44 (1995) 227-232.

[10] Betteridge K.J., Fléchon J.E., The anatomy and physiology of the preimplantation embryo, Theriogenology 29 (1988) 155-187.

[11] Bielanski A., A review on disease transmission studies in relationship to production of embryos by in vitro fertilization and to related new reproductive technologies, Biotech. Adv. 15 (1997) 633-656.

[12] Bielanskj A., Dubuc C., In vitro fertilization and culture of ova from heifers infected with bovine herpesvirus-1 (BHV-1), Theriogenology 41 (1994) 1211-1217.

[13] Bielanski A., Jordan L., Washing or washing and trypsin treatment is ineffective for removal of non-cytopathic bovine viral diarrhea virus from bovine oocytes or embryos after experimental viral contamination of an in vitro fertilization, Theriogenology 46 (1996) 1467-1476. 
[14] Bielanski A., Lutze Wallace C., Sapp T., Jordan L., The efficacy of trypsin for disinfection of in vitro fertilized bovine embryos exposed to bovine herpesvirus 1, Anim. Reprod. Sci. 47 (1997) 1-8.

[15] Blondin P., Sirard M.A., Oocyte and follicular morphology as determining characteristics for developmental competence in bovine oocytes, Mol. Reprod. Dev. 41 (1995) 54-62.

[16] Blondin P., Coenen K., Guilbault L.A., Sirard M.-A., In vitro production of bovine embryos: developmental competence is acquired before maturation, Theriogenology 47 (1997) 1061-1075.

[17] Booth P.J., Collins M.E., Jenner L., Prentice H., Ross P.J., Brownlie J., Isolation of virus from IVF bovine embryos infected in vitro with noncytopathogenic bovine viral diarrhea virus, following washing using IETS recommended procedures, in: Proc. AETE, Lyon, France, 1994, p. 154 (abstr.).

[18] Booth P.J., Stevens D.A., Collins M.E., Brownlie J., Detection of bovine viral diarrhoea virus antigen and RNA in oviduct and granulosa cells of persistently infected cattle, J. Reprod. Fert. 105 (1995) 17-24.

[19] Booth P.J., Collins M.E., Jenner L., Prentice H., Ross P.J., Brownlie J., Non-cytopathogenic bovine viral diarrhea virus (BVD) reduces cleavage but increases blastocyst yield of in vitro produced embryos, Theriogenology 50 (1998) 769-777.

[20] Bredbacka K., Bredbacka P., Glucose controls sex-related growth rate differences of bovine embryos produced in vitro. J. Reprod. Fert. 106 (1996) 169-172.

[21] Callesen H., Superovulation of cattle. Oocyte maturation, embryo quality and donor evaluation, Dr Vet. Sci. thesis, Royal Veterinary and Agricultural University, Copenhagen, 1995.

[22] Callesen H., Greve T., Hyttel P., Preovulatory endocrinology and oocyte maturation in superovulated cows, Theriogenology 25 (1986) 71-86.

[23] Callesen H., Løvendahl P., Bak A., Greve T., Factors affecting developmental stage of embryos recovered on day-7 from superovulated dairy cattle, J. Anim. Sci. 73 (1995) 1539-1543.

[24] Callesen H., Liboriussen T., Greve T., Practical aspects of multiple ovulation-embryo transfer in cattle, Anim. Reprod. Sci. 42 (1996) 215-226.

[25] Callesen H., Liboriussen T., Bak A., Application of embryo transfer, in: Liboriussen T., Andersen B.B. (Eds.), Embryo Transfer, Physiological Challenge Test and Nucleus Herd Breeding with Dairy Cattle, Report no. 737 , Danish Institute of Agricultural Sciences, Denmark, 1997, pp. 23-46.
[26] Camous S., Heyman Y., Meziou W., Menezo Y. Cleavage beyond the block stage and survival after transfer of early bovine embryos cultured with trophoblastic vesicles, J. Reprod. Fert. 72 (1984) 479-485.

[27] Carolan C., Lonergan P., Van Langendonckt A., Mermillod P., Factors affecting bovine embryo development in synthetic oviduct fluid following oocyte maturation and fertilization in vitro, Theriogenology 43 (1995) 1115-1128.

[28] Diez C., Le Bourhis D., Heyman Y., Renard J.P., Effect of partial lipid removal from in vitro produced bovine zygotes on further development in vitro and on the freezing tolerance of blastocysts, Theriogenology 45 (1996) 166 (abstr.).

[29] Du F., Looney C.R., Yang X., Evaluation of bovine embryos produced in vitro vs. in vivo by differential staining of inner cell mass and trophectoderm cells, Theriogenology 45 (1996) 211 (abstr.).

[30] Earl C., Kotaris P., Kelly J., Rowe J., Armstrong D.T., Gluthatione treatment of bovine sperm enhances in vitro blastocyst production rates, Theriogenology 47 (1996) 255 .

[31] Eckert J., Niemann H., In vitro maturation, fertilization and culture to blastocysts of bovine oocytes in protein-free media, Theriogenology 43 (1995) 1211-1225.

[32] Edwards R.F., Maturation in vitro of mouse, sheep, cow, pig, rhesus monkey and human ovarian oocytes, Nature 208 (1965) 349-351.

[33] Ellington J.E. The bovine oviduct and its role in reproduction: a review of the literature, Cornell Vet. 81 (1995) 313-328.

[34] Eyestone W.H., First N.L., Co-culture of early cattle embryos to the blastocyst stage with oviductal tissue or in conditioned medium, J. Reprod. Fert. 85 (1989) 715-720.

[35] Fair T., Hyttel P., Oocyte growth in cattle - ultrastructure, transcription and developmental competence, in: Motta P.M. (Ed.), Microscopy of Reproduction and Development: A Dynamic Approach, 1997, pp. 109-118.

[36] Fair T., Hyttel P., Greve T., Bovine oocyte diameter in relation to maturational competence and transcriptional activity, Mol. Reprod. Dev. 42 (1995) 437-442.

[37] Farin P.W., Farin C.E., Transfer of bovine embryos produced in vivo and in vitro: survival and fetal development, Biol. Reprod. 52 (1995) 676-682.

[38] Farin P.W., Britt J.H., Shaw D.W., Slenning B.D., Agreement among evaluators of bovine embryos produced in vivo or in vitro, Theriogenology 44 (1995) 339-349.

[39] Fukui Y., McGowan L.T., James R.W., Pugh P.A., Tervit H.R., Factors affecting the in-vitro development to blastocysts of bovine oocytes matured and fertilized in vitro, J. Reprod. Fert. 92 (1991) 125-131. 
[40] Galli C., Lazzari G., Practical aspects of IVM/IVF in cattle, Anim. Reprod. Sci. 42 (1996) 371-379.

[41] Gandolfi F., Brevini T.A.L., Modina S., Bianchi R., Passoni L., Role of the oviduct during early embryogenesis, Reprod. Dom. Anim. 28 (1993) 189-192.

[42] Gardner D.K., Changes in requirements and utilization of nutrients during mammalian preimplantation embryo development and their significance in embryo culture, Theriogenology 49 (1998) 83-102.

[43] Gardner D.K., Lane M., Spitzer A., Batt P.A., Enhanced rates of cleavage and development for sheep zygotes cultured to the blastocyst stage in vitro in the absence of serum and somatic cells: amino acids, vitamins, and culturing embryos in groups stimulate development, Biol. Reprod. 50 (1994) 390-400.

[44] Gardner D.K., Pawel-Czynski M., Trounson A.O., Nutrient uptake and ultilization can be used to select viable day 7 bovine blatocysts after cryopreservation, Mol. Reprod. Dev. 44 (1996) $472-475$.

[45] Garry F.B., Adams R., McCann J.P., Odde K.G., Postnatal characteristics of calves produced by nuclear transfer, Theriogenology 45 (1996) 141-152.

[46] Gonzales D.S., Pinherto J.C., Bavister B.D., Prediction of the developmental potential of hamster embryos in vitro by precise timing of the third cell cycle, J. Reprod. Fert. 105 (1995) 101108.

[47] Gordon I., Laboratory Production of Cattle Embryos, CAB International, Wallingford, UK, 1994.

[48] Greve T., Avery B., Callesen H., Viablity of invivo and in-vitro-produced bovine embryos, Reprod. Dom. Anim. 28 (1993) 164-169.

[49] Greve T., Callesen H., Hyttel P., Høier R., Assey P., The effect of exogenous gonadotropins on oocyte and embryo quality in cattle, Theriogenology 43 (1995) 41-50.

[50] Grippo A.A., Henault M.A., Anderson S.H., Killian G.J., Cation concentrations in fluid from the oviduct ampulla and isthmus of cows during the estrous cycle, J. Dairy Sci. 75 (1992) 58-65

[51] Grisart B., Massip A., Dessy F., Cinematographic analysis of bovine embryo development in serum-free oviduct-conditioned medium, J. Reprod. Fert. 101 (1994) 257-264.

[52] Guerin B., Nibart M., Marquant-Le Guienne B., Humblot P., Sanitary risks related to embryo transfer in domestic animals, Theriogenology 47 (1997) 33-42.

[53] Hasler J.F., McCauley A.D., Lathrop W.F., Foote R.H., Effect of donor-embryo-recipient interactions on pregnancy rate in a large-scale bovine embryo transfer program, Theriogenology 27 (1987) 139-168.
[54] Hasler J.F., Henderson W.N., Hurtgen P.J., Jin Z.Q., McCauley A.D., Mower S.A., Neely B.. Shuey L.S., Stokes J.E., Trimmer S.A., Production, freezing and transfer of bovine IVF embryos and subsequent calving results, Theriogenology 43 (1995) 141-152

[55] Hawk H.W., Gamete transport in the superovulated cow, Theriogenology 29 (1988) 125-142.

[56] Hawk H.W., Wall R.J., Improved yields of bovine blastocysts from in vitro-produced oocytes. II. Media and co-culture cells, Theriogenology 41 (1994) 1585-1594.

[57] Heyman Y., Overall bovine embryo transfer activity in Europe in 1996, Proc. 13th Sci. Meet. Eur. Emb. Trans. Soc., 1997, p. 67 (table).

[58] Holm P., Vajta G., Greve T., Callesen H., Pregnancy rates with direct transfer of vitrified and in-straw rehydrated intact and biopsied in vitro produced bovine embryos, Proc 12th Sci Meeting Eur. Emb. Trans. Assoc., 1996, p. 138 (abstr.).

[59] Holm P., Walker S.K., Seamark R.F., Embryo viability, duration of gestation and birth weight in sheep after transfer of in vitro matured and in vitro fertilized zygotes cultured in vitro or in vivo, J. Reprod. Fert. 107 (1996) 175-181.

[60] Holm P., Booth P.J., Vajta G., Callesen H., A protein-free SOF system supplemented with amino acids, sodium citrate and myo-inositol for bovine embryo culture, Proc. 13th Sci. Meet. Eur. Emb. Trans. Soc. 1997, p. 158 (abstr.).

[61] Holm P., Shukri N.N., Vajta G., Booth P., Bendixen C., Callesen H., Developmental kinetics of the first cell cycles of bovine in vitro produced embryos in relation to their in vitro viability and sex, Theriogenology 50 (1998) (in press).

[62] Hunter R.H.F., Low incidence of fertilisation in superovulated cows: a physiological explanation, Vet. Rec. 123 (1988) 443.

[63] Hunter R.H.F., Ovarian control of very low sperm/egg ratios at the commencement of mammalian fertilisation to avoid polyspermy, $\mathrm{Mol}$. Reprod. Dev. 44 (1996) 417-422.

[64] Hyttel P., Xu K.P., Smith S., Callesen H., Greve T., Ultrastructure of in vitro oocyte maturation in cattle, J. Reprod. Fert. 78 (1986) 615-625.

[65] Hyttel P., Callesen H., Greve T., Schmidt M., Oocyte maturation and sperm transport in superovulated cattle, Theriogenology 35 (1991) 91-108.

[66] Hyttel P., Fair T., Callesen H., Greve T., Oocyte growth, capacitation and final maturation in cattle, Theriogenology 47 (1997) 23-32.

[67] IETS (International Embryo Transfer Society), Manual of the IETS, Champaign, IL, USA, 1990, pp. 41-45.

[68] Itoh S., Goto T., Sex frequency of offspring from different developmental stage of cattle embryos, Jpn. J. AI Res. 8 (1986) 95-99. 
[69] Iwasaki S., Yoshiba N., Ushijima H., Watanab S. Nakahara T. J., Morphology and proportion of inner cell mass of bovine blastocysts fertilized in vitro and in vivo, J. Reprod. Dev. 90 (1990) 279-284.

170] Iwasaki S., Hamano S, Kuwayama M., Yamashita M., Ushijima H., Nagaoka S., Nakahara T., Developmental changes in the incidence of chromosome anomalies of bovine embryos fertilized in vitro, J. Exp. Zool. 261 (1992) 79-85.

[71] Jacobsen H., Sangild P., Schmidt M., Forhead A., Fowden A., Greve T., Plasma cortisol of fetal and premature newborn calves derived from in vitro produced embryos or artificial insemination, Proc 15th Sci. Meet. Eur. Emb. Trans. Assoc., 1998, 172 (abstr.).

[72] Jacobsen H., Holm P., Schmidt M., Sangild P., Greve T., Callesen H., In vitro embryo production versus artificial insemination: delivery type, birth weight and blood chemistry of the newborn calf, Theriogenology 51 (1999) (abstr.) (accepted for publication).

[73] Kane M.T., Morgan P.M., Coonan C., Peptide growth factors and preimplantation development, Hum. Reprod. Update 3 (1997) 137-157.

[74] Kawasaki S.J., Parvathi K.B., Stubbings R.B., Hansen P.J., King W.A., Chromosomal abnormalities in bovine embryos and their influence on development, Biol. Reprod. 54 (1996) 53-59.

[75] Keskintepe L., Brunley C.A., Brackett B.G., Production of viable bovine blastocysts in defined in vitro culture conditions, Biol. Reprod. 52 (1995) 1410-1417.

[76] Killian G.J., Chapman D.A., Kavanaugh J.F., Deaver D.R., Wiggin H.B., Changes in phospholipids, cholesterol and protein content of oviduct fluid of cows during the oestrous cycle, J. Reprod. Fert. 86 (1989) 419-426.

[77] King K.K., Seidel G.E. , Eisden R.P., Bovine embryo transfer pregnancies. I. Abortion rates and characteristics of calves, J. Anim. Sci. 61 (1985) 747-762.

[78] Kruip T.A.M, den Daas J.H.G., In vitro produced and cloned embryos: effects on pregnancy, parturition and offspring, Theriogenology 47 (1997) 43-52

[79] Lane M.W., Ahern T.J., Lewis I.M., Gardner D.K., Peura T.T., Cryopreservation and direct transfer of in vitro produced bovine embryos: a comparison between vitrification and slow-freezing, Theriogenology 49 (1998) 170 (abstr.).

[80] Lechniak D., Switonski M., Sosnowski M., The incidence of bovine diploid oocytes matured in vitro, Theriogenology 46 (2) (1996) 267-277.

[81] Leese H.J., The formation and function of oviduct fluid, J. Reprod. Fert. 82 (1988) 843-856.

[82] Leibfried-Rutledge M.L., Critser E.S., Eyestone W.H., Northey D.L., First N.L., Development potential of bovine oocytes matured in vitro or in vivo, Biol. Reprod. 36 (1987) 376-383.
[83] Leibo S.P., Pollard J.W., Martino A., Chilling and freezing sensitivity of "reassembled" in vitro-derived bovine embryos, Theriogenology 43 (1995) 265 (abstr.).

[84] Lindner G.M., Wright R.W., Bovine embryo morphology and evaluation, Theriogenology 20 (1983) 407-416.

[85] Loewen K.S., Del Campo M.R., Sirard M.A., Willadsen $S$., Isolation of bovine herpesvirus-1 (BHV-1) and bovine virus diarrhea virus (BVDV) in association with the in vitro production of bovine embryos, Theriogenology 40 (1993) 531-538.

[86] Lonergan P., Monaghen P., Rizos D., Boland M.P., Gordon I., Effect of follicle size on bovine oocyte quality and developmental competence following maturation, fertilization and culture in vitro, Mol. Reprod. Dev. 37 (1994) 48-53.

[87] Lonergan P., Carolan C., Thuard J.M., Marquant-Le Guienne B., Mermillod P., Embryo transfer and sex ratio of resulting calves following bovine embryo production in vitro, Proc. 1 lth Sci. Meet. Eur. Emb. Trans. Assoc., 1996, p. 202 (abstr.).

[88] Lorton S.P., First N.L., Hyaluronidase does not disperse the cumulus oophorus surrounding bovine ova, Biol. Reprod. 21 (1979) 301-308.

[89] Martal J., Chene N., Camous S., Huynh L., Lantier F., Hermier P., LHaridon R., Charpigny G., Charlier M., Chaouat G., Recent developments and potentialities for reducing embryo mortality in ruminants: the role of IFN-tau and other cytokines in early pregnancy, Reprod. Fert. Dev. 9 (1997) 355-80.

[90] Massip A., Mermillod P., Dinnyes A., Morphology and biochemistry of in vitro produced bovine embryos: implications for their cyropreservation, Hum. Reprod. 10 (1995) 3004-3011.

[91] McLaughlin K.J., McLean D.M., Stevens G., Ashman R.J., Lewis P.A., Bartsch B.D., Seamark R.F., Viability of one-cell bovine embryos cultured in synthetic oviduct fluid medium, Theriogenology 33 (1990) 1191-1199.

[92] Merton S., Project HGEP5, in vitro production of bovine embryos after Ovum Pick-Up, Research report October 1996-March 1997, Holland Genetics, 1997, 8 p.

[93] Merton S., van Wagtendonk-de Leeuw A.M., den Daas J.H.G., Factors affecting birthweight of IVP calves, Theriogenology 49 (1998) 293 (abstr.).

[94] Nagashima H., Kashiwazaki N., Ashman R.J., Grupen C.G., Nottle M.B., Cryopreservation of porcine embryos, Nature (Lond.) 374 (1995) 416.

[95] Nancarrow C.D., Hill J.L., Oviduct proteins in fertilization and early embryo development, J. Reprod. Fert. (Suppl.) 49 (1995) 3-13. 
[96] Nicholas F.W., Genetic improvement through reproductive technology, Anim. Reprod. Sci. 42 (1996) 205-214.

[97] O'Kearney-Flynn M., Wade M., Dufy P., Gath V., Boland M.P;, Dobrinsky J.R., Effect of cryopreservation on IVP cattle embryo development in vitro and in vivo, Theriogenology 49 (1998) 173 (abstr.).

[98] Overström E.W., In vitro assessment of embryo viability, Theriogenology 45 (1996) 3-16.

[99] Overström E.W., Embryos respiration as an objective measure of embryo quality, Proc. Satellite Workshop on Emb. Dev. In vitro: current challenges and future concepts at the Ann. Conf. IETS, Boston, MA, USA, 1998, pp. 22-23.

[100] Parrish J.J., Susko-Parrish J., Liebfried-Rutledge M.L., Critser E.S., Eyestone W.H., First N.L., Bovine in vitro fertilization with frozen-thawed semen, Theriogenology 25 (1986) $591-600$.

[101] Partridge R.J., Pullar D., Wrathball A.E., Leese H.J., Consumption of amino acids by in vivo and in vitro-derived bovine embryos, Theriogenology 45 (1996) 181 (abstr.).

[102] Pavlok A., Lucas-Hahn A., Niemann H., Fertilization and developmental competence of bovine oocytes derived from different categories of antral follicles, Mol. Reprod. Dev. 31 (1992) 63-67.

[103] Pieterse M.C., Kapper K.A., Kruip T.A.M., Taverne M.A.M., Aspiration of bovine oocytes during transvaginal ultrasound scanning of the ovaries, Theriogenology 30 (1988) 751-762.

[104] Pinyopummintr T., Bavister B.D., In vitro matured/in vitro fertilized bovine oocytes can develop into morulae/blastocysts in chemically defined, protein-free culture media, Biol. Reprod. 45 (199l) 736-742.

[105] Pinyopummintr T., Bavister B.D., Development of bovine embryos in a cell-free culture medium: effect of type of serum, timing of its inclusion and heat inactivation, Theriogenology 41 (1994) 1241-1249.

[106] Plante L., King W.A., Light and electron microscopic analysis of bovine embryos derived by in vitro and in vivo fertilization, J. Assist. Reprod. Gen. 11 (1994) 515-529.

[107] Pollard J.W., Leibo S.P., Comparative cryobiology of in vitro and in vivo derived bovine embryos, Theriogenology 39 (1993) 287 (abstr.).

[108] Pollard J.W., Leibo S.P., Chilling sensitivity of mammalian embryos, Theriogenology 41 (1994) 101-106.

[109] Prather R.S., First N.L., Cell-to-cell coupling in early stage bovine embryos: a preliminary report, Theriogenology 39 (1993) 561-567.

[110] Reichenbach H.D., Liebrich J., Berg U., Brem G., Pregnancy rates and births after unilateral or bilateral transfer of bovine embryos produced in vitro, J. Reprod. Fert. 95 (1992) 363-370.
[111] Reinders J.M.C., Wurth Y.A., Kruip T.A.M., From embryo to a calf after embryo transfer, a comparison of in vivo and in vitro produced embryos, Theriogenology 43 (1995) 306 (abstr.).

[112] Renard J.P., Phillipon A., Menezo Y., In vitro uptake of glucose by bovine blastocysts, J. Reprod. Fert. 58 (1980) 161-164.

[113] Rieger D., Relationship between energy metabolism and development of early mammalian embryos, Theriogenology 37 (1992) 75-94.

[114] Rieger D., Grisart B., Semple E., Van Langendonckt A., Betteridge K.J., Dessy F., Comparison of the effects of oviductal cell-conditioned medium on the development and metabolic activity of cattle embryos, J. Reprod. Fert. 103 (1995) 9!-96.

[115] Rosenkranz C.F. Jr., First N.L., Effect of free amino acids and vitamins on cleavage and developmental rate of bovine zygotes in vitro, J. Anim. Sci. 72 ( 1994 ) 434-437.

[116] Rosenkranz C.F. Jr., Zeng G.Q., McNamara G.T., Schoff P.K., First N.L., Development of bovine embryos in vitro as affected by energy substrates, Biol. Reprod. 49 ( 1993 ) 459-62.

[117] Schmidt M., Greve T., Avery B., Beckers J.F., Sulon J., Hansen H.B., Pregnancies, calves and calf viability after transfer of in vitro produced bovine embryos, Theriogenology 46 (1996) 527-539.

[118] Schmidt M., Sangild P.T., Jacobsen H., Avery B., Greve T., No effect of in vitro production of embryos on size and organ weights in premature newborn calves, Proc. 14th Sci. Meet. Eur. Emb Trans. Assoc., 1998, p. 244 (abstr.).

[119] Sinclair K.D., Broadbent P.J., Dolman D.F., Taylor A.G., Reaper J.F., In vitro produced embryos as a means of achieving pregnancy and improving productivity in beef cows, Theriogenology 41 (1994) 294 (abstr.).

[120] Sinclair K.D., McEvoy T.G., Carolan C., Maxfield E.K., Maltin C.A., Yong L.E., Wilmut I., Robinson J.J., Broadbent P.J., Conceptus growth and development following in vitro culture of ovine embryos in media supplemented with bovine sera, Theriogenology 49 (1998) 218 (abstr.).

[121] Sirard M.A., Blondin P., Oocyte maturation and IVF in cattle, Anim. Reprod. Sci. 42 (1996) $417-426$.

[122] Sloss V., Dufty J.H., Handbook of Bovine Obstetrics, Williams and Wilkins, Baltimore/London, 1980, pp. 88-90.

[123] Sneessens E., Grisart B., Massip A., Dessy F., Kinetics of development and sex-ratio of bovine blastocysts produced either in co-culture or in serum-free conditioned medium, Proc. 13th Sci. Meet. Eur. Emb. Trans. Assoc., 1997, p. 244 (abstr.). 
[124] Stringfellow D.A., Wrathhall A.E., Epidemiological implications of the production and transfer of IVF-embryos, Theriogenology 43 (1995) 89-96.

[125] Tajik P., Niwa K., Murase T., Effects of different protein supplements in fertilization medium on in vitro penetration of cumulus-intact and cumulus-free bovine oocytes matured in culture, Theriogenology 40 (1993) 949-958.

[126] Takahashi Y., First N.L., In vitro development of bovine one-cell embryos: influence of glucoce, lactate, pyruvate, amino acid and vitamins, Theriogenology 37 (1992) 963-978.

[127] Tervit H.R., Whittingham D.G., Rowson L.E.A., Successful culture of sheep and cattle ova, J. Reprod. Fert. 30 (1972) 177-179.

[128] Tervit H.R., Pugh P.A., McGowan L.T, Bell A.C.S., Wells R.W., The freezability of sheep embryos is affected by culture system and source (in vivo- or in vitro-derived), Theriogenology 41 (1994) 315 (abstr.).

[129] Thompson J.G., Defining the requirements for bovine embryo culture, Theriogenology 45 (1996) 27-40.

[130] Thompson J.G., Comparison between in vivoderived and in-vitro-produced pre-elongation embryos from domestic ruminants, Reprod. Fert. Develop. 9 (1997) 341-354.

[131] Thompson J.G., Dunganzich D., Analysis of culture systems for bovine in vitro embryo production, reported in abstracts of the proceedings of the International Embryo Transfer Society (1991-1995), Theriogenology 45 (1996) 195.

[132] Thompson J.G.E., Simpson A.C., Pugh P.A., Wright R.W. Jr., Tervit H.R., Glucose utilization by sheep embryos derived in vivo and in vitro Reprod. Fert. Develop. 3 (1991) 571-576.

[133] Thompson J.G., Gardner D.K., Pugh A.P., McMillan W.H., Tervit H.R., Lamb birth weight is affected by culture system utilized during in vitro pre-elongation development of ovine embryos, Biol. Reprod. 53 (1995) 1385-1391.

[134] Thompson J.G., Bell A.C.S., Tervit H.R., Utilisation of $[1-14 C]$-pyruvate by day 6 ovine blastocysts derived from in vivo or in vitro sources, Proc. 13th Int. Con. Anim. Reprod., Sydney, Australia, 1996, p. 22-4 (abstr.).

[135] Thompson J.G., Allen N.W., McGowan L.T., Bell A.C.S., Lamber M.G., Tervit H.R., Effects of delayed supplementation of fetal calf serum to culture medium on bovine embryo development in vitro and following transfer, Theriogenology 49 (1998) 1239-1249.

[136] Twagiraumngu H., Morin N., Bordignon V., Smith L.C., Bousquet D., Influence of serum in culture system on the production and cryopreservation of in vitro-derived bovine embryos, Theriogenology 47 (1997) 356 (abstr.).
[137] Ushijima H., Yamakawa H., Nagashima H. Cryopreservation of bovine IVM/IVF embryos at early cleavage stages following removal of cytoplasmic lipid droplets, Theriogenology 45 (1996) 159 (abstr.).

[138] Vajta G., Holm P., Callesen H., Greve T., Overall efficiency of in-vitro embryo production and vitrification in cattle. Theriogenology 45 (1996) 683-689.

[139] Vajta G., Booth P.J., Holm P., Greve T., Callesen $H$., Successful vitrification of early stage bovine in vitro produced embryos with the open pulled straw (OPS) method, Cryo-Lett. 18 (1997) 191-195.

[140] Van Langendonckt A., Donay I., Schuurbiers N., Auquier P., Carolan C., Massip A., Dessy F., Effects of supplementation with fetal calf serum on development of bovine embryos in synthetic oviduct fluid medium, J. Reprod. Fert. 109 (1997) 87-93.

[141] Van Soom A., Bols P.E.J., Vanroose G., de Kruif $A$., A comparison between in vivo and in vitro produced bovine embryos: scientific and practical implications, Proc. 12th Int. Con. Anim. Reprod. AI 3 (1992) 1365-1367.

[142] Van Soom A., Mijten P., Van Vlaenderen I., Van den Branden J., Mamoudzadeh A.R., de Kruif A., Birth of double-muscled Belgian Blue calves ofter transfer of in vitro produced embryos into dairy cattle, Theriogenology 41 (1994) 855-867.

[143] Van Soom A., Boerjan M., Ysebaert M.-T., de Kruif A., Cell allocation to the inner cell mass and the trophectoderm in bovine embryos cultured in two different media, Mol. Reprod. Dev. 45 (1996) 171-182.

[144] Van Soom A., Van de Velde A., Van Langendonckt A., de Kruif A., Sucrose-induced shrinkage of in vitro produced bovine morulae: effect on viability, morphology and ease of evaluation, Theriogenology 46 (1996) 1131-1147.

[145] Van Soom A., Boerjan M.L., Bols P.E., Vanroose G., Lein A., Coryn M., deKruif A., Timing of compaction and inner cell allocation in bovine embryos produced in vivo after superovulation, Biol. Reprod. 57 (1997) 104I-1049.

[146] Voekel S.A., Hu Y.X., Moore K., Bondioli K.R., Freeze survival of bovine embryos produced by in vitro maturation, fertilization and culture of oocytes, Theriogenology 37 (1992) 317 (abstr.).

[147] Wagtendonk-de Leeuw van A.M., Aerts B.J.G., den Daas J.H.G., Abnormal offspring following in vitro production of bovine preimplantation embryos: a field study, Theriogenology 49 (1998) 883-894.

[148] Walker S.K., Heard T.M., Seamark R.F., In vitro culture of sheep embryos without co-culture: successes and perspectives, Theriogenology 37 (1992) $11-126$. 
[149] Walker S.K., Hartwich K.M., Seamark R.F., The production of unusually large offspring following embryo manipulation: concepts and challenges, Theriogenology 45 (1996) 111-120.

[150] Wegner C.C., Killian G.J., In vitro and in vivo association of an oviduct estrus-associated protein with bovine zona pellucida, Mol. Reprod. Dev. 29 (1991) 77-84.

[151] Willadsen S.M., Janzen R.E., McAlister R.J., Shea B.F., Hamilton G., McDerman D., The viability of late morulae and blastocysts produced by nuclear transplantation in cattle, Theriogenology 35 (1991) 161-170.

[152] Wrenzycki C., Carnwath J.W., Niemann H., Expression of the gap junction gene Conexin43 $(\mathrm{C} \times 43)$ in preimplantation bovine embryos derived in vivo or in vitro, Theriogenology 45 (1996) 251 (abstr.).

[153] Wrenzycki C., Herrmann D., Lemme E., Eckert J.W., Carnwath J.W., Niemann H., Expression of developmentally important genes in preimplantation bovine embryos generated in vitro, Theriogenology 47 (1997) 220 (abstr.).

[154] Wrenzycki C., Herrmann D., Lemme E., Korsawe J.W., Carnwath J.W., Niemann H., Determination of the relative abundance of various developmentally important gene transcripts in bovine embryos generated in vitro or in vivo using a semi-quantitative RT-PCR assay, Proc. Satellite Workshop on Emb. Dev. In Vitro: Current Challenges and Future Concepts at the Ann. Conf. IETS, Boston, MA, USA, 1998, p. 14 (abstr.).

[155] Wright R.W., Ellington J., Morphological and physiological differences between in vivo- and in vitro-produced preimplantation embryos from livestock species, Theriogenology 44 (1995) 1167-1189.

[156] Wurth Y.A., Reinders J.M.C., Rall W.F., Kruip T.A.M., Developmental potential of in vitro produced bovine embryos following cryopreservation and single-embryo transfer, Theriogenology 42 (1994) 1275-1284.

[157] Xu K.P., Greve T., A detailed analysis of early events during in-vitro fertilization of bovine follicular oocytes, J. Reprod. Fert. 82 (1988) 127-134.

[158] Xu K.P., Yadav B.R., King W.A., Betteridge K.J., Sex-related differences in developmental rates of bovine embryos produced and cultured in vitro, Mol. Reprod. Dev. 31 (1992) 249-252.

[159] Yadav B.R., King W.A., Betteridge K.J., Relationships between the completion of the first cleavage and the chromosomal complement, sex and developmental rates of bovine embryos generated in vitro, Mol. Reprod. Dev. 36 (1993) 434-439.

[160] Yoshioka K., Othman A.M., Taniguchi T., Yamanaka H., Sekikawa K., Differential patterns of blastulation in bovine morulae cultured in synthetic oviduct fluid medium containing FCS or BSA, Theriogenology 48 (1997) 997-1008.

[161] Young L.E., Butterwith S.C., Wilmut I., A novel method for quantifying mRNA levels in single embryos, Theriogenology 49 (1998) 192 (abstr.).

[162] Zurovac O.V., Stringfellow D.A., Brock K.V., Riddell M.G., Wright J.C., Noncytopathic bovine viral diarrhea virus in a system for in vitro production of bovine embryos, Theriogenology 41 (1994) 841-853. 